\title{
Exemplary Knowledge Transfer Between Germany and Patagonia as Contribution to the Regional Achievement of the UN Sustainable Development Goals 2030
}

\author{
Walentowski $\mathrm{H}^{1 *}$, Hohnwald $\mathrm{S}^{1}$, Thren $\mathrm{M}^{1}$, Kappas $\mathrm{M}^{2}$, Leuschner $\mathrm{C}^{3}$, Lencinas JD ${ }^{4}$, Bava J0 ${ }^{4}$, \\ Loguercio $\mathrm{G}^{4}$, Urretavizcaya $\mathrm{F}^{4}$, Barrotaeveña $\mathrm{C}^{4}$, Martínez Pastur $\mathrm{GJ}^{5}$ and Zerbe $\mathrm{S}^{6}$ \\ ${ }^{1}$ Faculty of Resource Management, University of Applied Sciences and Arts [HAWK], Germany \\ ${ }^{2}$ Department Cartography, GIS and Remote Sensing, Georg-August-University Göttingen, Germany \\ ${ }^{3}$ Albrecht-von-Haller-Institute for Plant Sciences, Georg August-University-Göttingen, Germany \\ ${ }^{4}$ Research and Extension Center Andean Patagonian Forest [CIEFAP], Esquel, Argentina \\ ${ }^{5}$ Centro Austral de Investigaciones Científicas [CADIC CONICET], Ushuaia, Tierra del Fuego, Argentina \\ ${ }^{6}$ Faculty of Science and Technology, Free University of Bozen - Bolzano, Italy \\ *Corresponding author: Walentowski H, Faculty of Resource Management, University of Applied Sciences and Arts [HAWK], \\ Göttingen, Germany
}

\section{ARTICLE INFO}

Received: 幽 February 10, 2020

Published: February 18, 2020

Citation: Walentowski H, Hohnwald S, Thren M, Kappas M, Leuschner C, et al., Exemplary Knowledge Transfer Between Germany and Patagonia as Contribution to the Regional Achievement of the UN Sustainable Development Goals 2030. Biomed J Sci \& Tech Res 25(4)-2020. BJSTR. MS.ID.004242.

Keyword: Global Warming; Natural Risks; Forest Ecosystems; Sustainable Land Use; Cooperative Research; Global Partnership

\begin{abstract}
Concerted efforts are required to achieve the UN Sustainable Development Goals (SDGs) of the 2030 Agenda. In our study, we intend to outline how valuable synergy effects can be obtained from bilateral cooperation between Germany and Patagonia in order to protect temperate forest ecosystems and to ensure long-term and sustainable use of terrestrial natural resources. The additional benefit of this transcontinental and transhemispherical cooperation is that there are analogies between the Northern and Southern hemispheres, but also distinct differences that complement each other perfectly. We show in an exemplary way, how the challenges of Global Warming and the associated increased vulnerability to forest fires and other natural risks can be tackled. Knowledge transfer and common strategies will provide sound solutions for SDG 13 (urgent action to combat climate change and its impacts), SDG 15 (sustainable use of terrestrial ecosystems, sustainably managed forests, combating desertification, and halting and reversing land degradation and halting biodiversity loss) and SDG 17 (strengthening the means of implementation and revitalizing the global partnership for sustainable development).
\end{abstract}

\section{Introduction}

In order to achieve the UN Sustainability Goals 2030 (SDGs; Figure 1), a broad range of knowledge and expertise is required, as well as consensual quality standards and scientifically aligned ways. It represents an enormous challenge to achieve a sustainable land use, and at the same time, to stop biodiversity destruction associated to profound human impacts on Earth's ecosystems [1]. Here, we have to consider not only the human direct impact, but also the effects of climate change on abiotic plant stress (SDG 13: Climate Action). The Sword of Damocles hanging over terrestrial biodiversity (SDG 15: Life on Land) is the imminent and ever-present peril of increasing risks of unpredictable hazards due to the climate change, e.g. desertification, forest fires, hurricanes, floodings, and different diseases. Undoubtedly, we need a worldwide cooperative scientific research and a global political challenge to tackle this 
issue (SDG 17: Partnerships to achieve the Goal). A fundamental aspect is to intensify cooperation and interface research for finding innovative solutions for achieving the SDGs. Research results have to be interconnected with a global knowledge transfer in order to transfer sustainable land-use knowledge, locally adapted to the regions where needed. Moreover, we need a rapid progress of this agenda to develop management, conservation, and restoration strategies that increase the forest resilience to these threats. Most notably, we have to support the creativity, fresh ideas and new skills of our students and junior researchers. They must be our priority, because as future experts and world citizens they carry our hope for the future. We are convinced that a dynamic interaction of local and transhemispheric networks offer a strong opportunity for proper solution approaches. (Figure 1) The focused goals of the German-Patagonian cooperation [SDGs 13, 15, and 17] are framed.

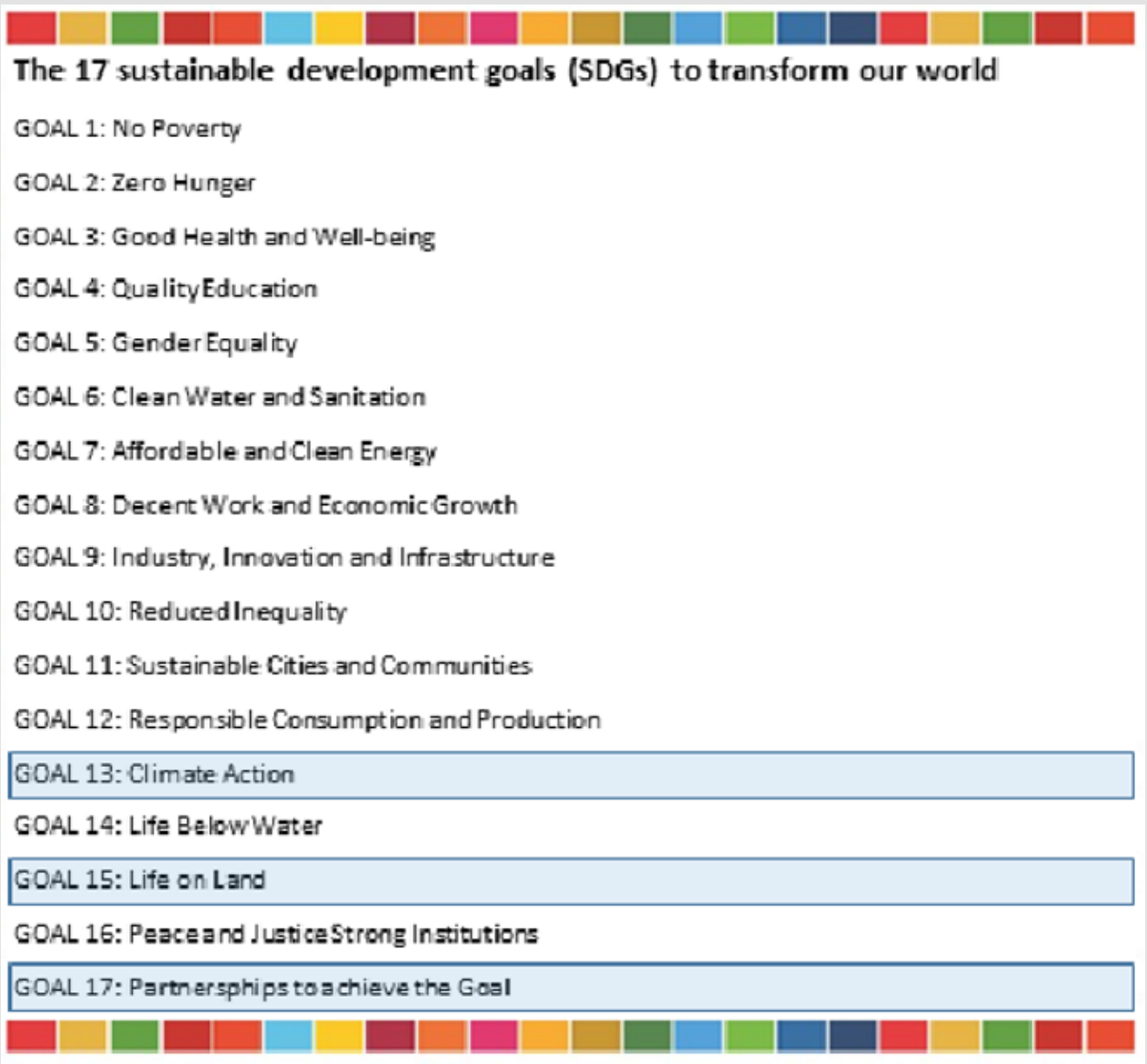

Figure 1: The 17 Sustainable Development Goals.

Goal 13: Take urgent action to combat climate change and its impacts.

Goal 15: Protect, restore and promote sustainable use of terrestrial ecosystems, sustainably manage forests, combat desertification, and halt and reverse land degradation and halt biodiversity loss.

Goal 17: Strengthen the means of implementation and revitalize the global partnership for sustainable development.

\section{Case Example of Bilateral, Transhemispheric Knowledge Transfer between Germany and Patagonia}

Using four concrete case examples, we conducted a mini review on recent research, suitable to create synergistic results and innovation

\section{Knowledge Transfer in the Field of 'Managed Forests $\propto>$ Primary Unmanaged Forests'}

1. Exchanging experiences from sustainably managed Fagus sylvatica forests (integrative multifunctional forest management to reconcile biodiversity conservation and timber production) in Germany [2,3].

2. Exchanging experiences from Andean-Patagonian Nothofagus forest region [4]. The region exhibits full-length sequences of temperate deciduous (Nothofagus pumilio, $N$. dombeyi, $N$. alpina, $N$. obliqua), semi-deciduous mixed (Nothofagus-Austrocedrus), brushwood (pioneer species such as Nothofagus antarctica, Lomatia hirsuta, Maytenus boaria), and coniferous forests (Austrocedrus chilensis) along both altitudinal and lateral climatic gradients [5], simulating 
increased summer drought and heat stress, which are expected for central parts of the Fagus sylvatica region in Germany by global climate models [6].

\section{Knowledge Transfer in the Field of 'Post-Fire Succession $\leftrightarrow$ Forest Development Types (FDT)'}

1. Learning about the effects of forest fires on succession dynamics and ecosystem functions from Andean-Patagonian Nothofagus forest region $[7,8]$.

2. Learning from concepts of potential natural vegetation (PNV) and FDT from Germany $[9,10]$.

\section{Knowledge Transfer in the Field of 'Non-Native Conifer Plantations'}

1. Learning from ecosystem services offered by low-mediumscale Pinus ponderosa plantations established on degraded grassland from Patagonia [11] (storage and sink of carbon [12], soil protection, pioneer shelter forests for future native species, additional income opportunities through cattle pasture and non-timber products, for example mushroom cultivation) [13].

2. Comprehensive benefit-risk assessment of Pseudotsuga menziesii plantations within Germany [14] and Patagonia [15].

Knowledge Transfer in the Field of 'Traditional Land Use', including Different Types of Agrosilvopastoral Systems, their Historical, Current and Future Significance, Identifying Indicators of Sustainability and Biodiversity, and Ecosystem Services

1. Exchanging experiences from Dehesas / Montados [16] to Germany and Patagonia.

2. Exchanging experiences from silvopastoral systems in Patagonia, Argentina [17].

Research results and Knowledge Transfer should be Integrated in Common, Although Locally Adapted, Strategies for Sustainable Land Use

1. Ideas and concepts for risk diversification, resourceefficiency, transfer of technology, climate mitigation and climate-efficient land use [18].

2. Restoration of degraded forest land towards multifunctional and biodiverse forest ecosystems [19].

3. Developing efficient strategies against desertification of forest and agricultural landscapes and the erosion of valuable volcanic ash soils (soil conservation and clean water) [20].

4. Expansion of non-wood forest products (Myco-forestry [truffle growing / mushroom cultivation on deadwood] / forest farming) [21].
5. Cascade use to increase the efficiency of carbon storage [22].

6. Life cycle assessment for timber forest products (cost and process optimization) [23].

7. Inclusion of the treasure of experience of indigenous people and local communities in sustainable transformation research [24].

8. Optimization of forest monitoring systems [25], development of an Adaptable Integrated Data Information System (AIDIS) and data cube as a planning and decision platform and tool based on geographic information systems (ArcGIS Pro and Open Source GIS (e.g. QGIS) [26].

\section{How We Can Contribute to SDGs?}

Forests in Patagonia still present a relatively good conservation status and are well represented in the natural areas. However, the negative synergies of different human derived impacts (e.g. direct as harvesting or indirect by invasive species) promote significant changes in the natural ecosystems. Contrary, Germany is characterized by the complete loss of sylvatic mosaics of larger forest complexes (wilderness areas) and promotes the simplification of remnants of its natural forests, mainly to increase the provisioning ecosystem services. However, during the last decades they starting to recover part of the natural heterogeneity of the natural forests, allowing to increase the provision of other ecosystem services and biodiversity conservation. For this, the dynamic interaction of local and transhemispheric networks generates an added value that complements the gap knowledge based on the forest management and conservation objectives. These objectives were clearly related to SDGs. The climate change will directly affect forestry and conservation in both countries (SDG 13: Climate Action).

The collaboration allows to define new silvicultural and conservation strategies (e.g. regeneration or habitat maintenance for different target species), models for adaptive forest management and promotes the agreement of a common agenda for management and conservation planning at landscape level. These topics are also closely related to the assemblage of terrestrial biodiversity (SDG 15: Life on Land) in productive lands (e.g. managed stands) and those forests left-aside of timber purposes (e.g. natural reserves). During the last century, land degradation has continued, where biodiversity loss occurring at an alarming rate, mainly due to invasive species, which reduce the resilience of natural forests. For this, new management strategies must be developed to protect the natural forests, ensuring long-term and sustainable use of terrestrial natural resources. Finally, to achieve these tasks, a collective intelligence with a strong worldwide cooperative scientific research is required (SDG 17: Partnerships to achieve the Goal), where connection from developed to moderately or less developed countries is crucial. Enhanced international cooperation is needed to ensure that sufficient means of implementation exist to provide countries the opportunity to achieve the SDGs. 


\section{References}

1. Ripple WJ, Wolf C, Newsome TM, Mauro Galetti, Mohammed Alamgir, et al. (2017) World Scientists' Warning to Humanity: A Second Notice. BioScience 67 (12): 1026-1028.

2. Winter S (2016) practice handbook - nature conservation in the beech forest $2^{\text {nd }}(\mathrm{edn}$.$) . pp. 186$.

3. Kraus D (2016) Catálogo de los microhábitats de los árboles - Lista de campos de referencia. Integrate+ Technical Paper13: 16.

4. Loguercio G, Donoso PJ, Müller Using S, Dezzotti A, Urretavizcaya MF, et al. (2018) Silviculture of temperate mixed forests from South America. In: Bravo Oviedo A, Pretzsch H, del Río M (Eds.) Dynamics, Silviculture and Management of Mixed Forests 271-317.

5. Seibert P (1982) Carta de vegetación de la región de El Bolsón, Rio Nego y su aplicación a la planificación del uso de la tierra. Doc Physiosociol 2: $1-120$.

6. Walentowski H, Falk W, Mette T, Kunz J, Bräuning A, et al. (2017) Assessing future suitability of tree species under climate change by multiple methods: a case study in southern Germany. Annals of Forest Research 60 (1):101-126.

7. Guadalupe Franco M, Mundo IA, Veblen TT (2020) Field-Validated BurnSeverity Mapping in North Patagonian Forests. Remote Sens 12(2): 214

8. Veblen TT, Kitzberger T, Raffaele E, Mermoz M, González ME, et al. (2008) The historical range of variability of fires in the Andean-Patagonian Nothofagus forest region. International Journal of Wildland Fire 17(6): 724-741.

9. Bohn U, Neuhäusl R, Gollub G, Hettwer C, Neuhäuslová Z, et al. (2000 2003) Karte der natürlichen Vegetation Europe. Maßstab 1:2,500,000. Teil 1-3 [Map of the Natural Vegetation of Europe. Scale 1: 2.5 million. Part 1-3]. Landwirtschaftsverlag, Münster: pp. 655.

10. (2004) Lower Saxony State Forest (NLF) Long-term ecological forest development, guideline for the selection of tree species [in German]. Vol. 54 , 'from the forest', Hannover.

11. Bava JO, Loguercio GA, Salvador G (2015) ¿Por qué plantar en Patagonia? Estado actual y el rol futuro de los bosques plantados. Ecología Austral 25(2): 101-111.

12. Laclau P (2003) Biomass and carbon sequestration of ponderosa pine plantations and native cypress forests in northwest Patagonia. Forest Ecology and Management 180(1-3): 317-333.

13. Barroetaveña C, La Manna L, Alonso MV (2008) Variables affecting Suillus luteus fructification in ponderosa pine plantations of Patagonia (Argentina). Forest Ecology and Management 256(11): 1868-1874.

\section{ISSN: 2574-1241}

\section{DOI: $10.26717 /$ BJSTR.2020.25.004242}

Walentowski H. Biomed J Sci \& Tech Res

This work is licensed under Creative Commons Attribution 4.0 License

Submission Link: https://biomedres.us/submit-manuscript.php
14. Bindewald A, Michiels HG, Bauhus J (2019) Risk is in the eye of the assessor: comparing risk assessments of four non-native tree species in Germany. Forestry: An International Journal of Forest Research, cpz052: 1-16.

15. Nuñez MA, Paritsis J (2018) How are monospecific stands of invasive trees formed? Spatio-temporal evidence from Douglas fir invasions. AoB PLANTS 10(4): ply041.

16. Schnabel S, Ferreira A (2004) Sustainability of Agrosilvopastoral Systems - Dehesas, Montados. Advances in Geoecology 37: 389.

17. Peri PL, Caballé G, Hansen NE, María V, Lencinas Axel R, et al. (2017) Sylvopastoral systems in Patagonia, Argentina. In: Gordon AM, Newman SM, Coleman BRW (Eds.) Temperate Agroforestry Systems, $\left(2^{\text {nd }}\right.$ edn.): 252-273.

18. Fritsche UR, Eppler U, Iriarte L, Sabine Laaks, Stepanie Wunder, et al. (2015) Resource-Efficient Land Use - Towards a Global Sustainable Land Use Standard (GLOBALANDS). Umweltbundesamt Texte 82: 101.

19. Zerbe S (2019) Restoration of ecosystems in the area of tension between humans and the environment [in German]. Springer Spektrum, pp. 731.

20. Mazzoni E, Vazquez M (2009) Desertification in Patagonia. In: Latrubesse E (Ed.) Natural Hazards and Human-Induced Disasters in South America. Developments in Earth Surface Processes 13: 351-377.

21. Cotter T (2014) Organic Mushroom Farming and Mycoremediation: Simple to Advanced and Experimental Techniques for Indoor and Outdoor Cultivation. Chelsea Green Publishing, pp. 400.

22. Brunet Navarro P, Jochheim H, Kroiher F, Muys B (2018) Effect of cascade use on the carbon balance of the German and European wood sectors. J Cleaner Production 170: 137-146.

23. Bosner A, Poršinsky T, Stankić I (2012) Forestry and Life Cycle Assessment. In: Okia CA (Ed) Global Perspectives on Sustainable Forest Management: 139-160.

24. Lam DE, Hinz, Lang, D, Tengö M, von Wehrden H, et al. (2020) Indigenous and local knowledge in sustainability transformations research: a literature review. Ecology and Society 25(1): 3.

25. Díaz G, Mohr Bell D, Garrett M, Muñoz L, Lencinas JD (2020) Customizing unmanned aircraft systems to reduce forest inventory costs: can oblique images substantially improve the $3 \mathrm{D}$ reconstruction of the canopy? International Journal of Remote Sensing, 41(9): 3480-3510.

26. Flügel WA (2007) The adaptive integrated data information system (AIDIS) for global water research. Water Resources Management 21(1): 199-210.

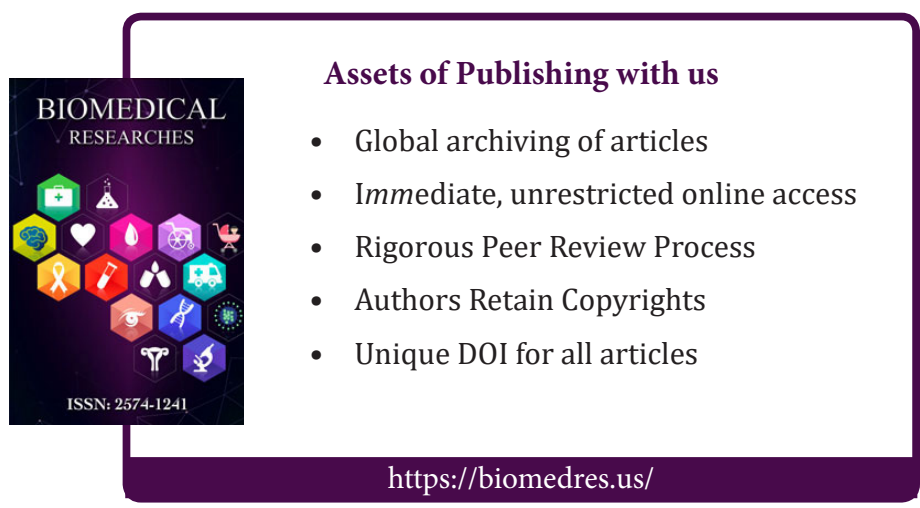

